\title{
ANALISIS PEMAHAMAN KONSEP SISWA PADA MATERI PENCEMARAN LINGKUNGAN DI SMA NEGERI 4 PALEMBANG
}

\author{
Aseptianova $^{1)}$, Sulton Nawawi ${ }^{2)}$ Lia Pesisa $^{3)}$ a) \\ 1) 2) 3) Pendidikan Biologi Fakultas Keguruan dan Ilmu Pendidikan Universitas Muhammadiyah \\ Palembang, \\ Jl. Jendral Ahmad Yani 13 Ulu Seberang Ulu II, Kec. Plaju, Kota Palembang \\ a)pesisalia@gmail.com \\ Telp: +62-823-8017-8004
}

\begin{abstract}
This study aims to determine students' understanding of the concept of environmental pollution material in the school of SMAN 4 Palembang. This type of research is quantitative descriptive. The population of this study were all students of class XI MIPA SMAN 4 as many as 161 students. Sampling uses total sampling technique. Data collection techniques using test questions understanding concepts. The results of the study based on the analysis carried out using the percentage level of understanding of students 'concepts showed that students' understanding of concepts in environmental pollution material at Palembang State High School 4 was at high criteria with an average value of $65 \%$. Conclusion the students' conceptual comprehension ability in environmental pollution material at Palembang State High School 4 with the highest value is found in the classifying indicator of $86 \%$ with very high criteria, and the lowest indicator is in the concluding indicator which is equal to $48 \%$ with the criteria being.
\end{abstract}

Key words: Understanding the concept, environmental pollution

\begin{abstract}
ABSTRAK
Penelitian ini bertujuan untuk mengetahui pemahaman konsep siswa terhadap materi pencemaran lingkungan di SMA Negeri 4 Palembang. Jenis penelitian ini adalah deskriptif kuantitatif. Populasi penelitian ini adalah seluruh siswa kelas XI MIPA SMA Negeri 4 Palembang sebanyak 161 siswa. Pengambilan sampel menggunakan teknik total sampling. Teknik pengumpulan data menggunakan lembar soal tes pemahaman konsep. Hasil penelitian berdasarkan analisis yang dilakukan menggunakan persentase tingkat pemahaman konsep siswa menunjukkan bahwa pemahaman konsep siswa pada materi pencemaran lingkungan di SMA Negeri 4 Palembang berada pada kriteria tinggi dengan nilai rata-rata sebesar $65 \%$. Kesimpulan kemampuan pemahaman konsep siswa pada materi pencemaran lingkungan di SMA Negeri 4 Palembang dengan nilai tertinggi yaitu terdapat pada indikator mengklasifikasikan sebesar $86 \%$ dengan kriteria sangat tinggi, dan Indikator terendah terdapat pada indikator menyimpulkan yaitu sebesar $48 \%$ dengan kriteria sedang.
\end{abstract}

Kata kunci: Pemahaman konsep, pencemaran lingkungan 


\section{PENDAHULUAN}

Pendidikan merupakan sebagai usaha manusia untuk menumbuhkan dan mengembangkan potensi pembawaan, baik jasmani maupun rohani sesuai dengan nilainilai yang ada serta usaha-usaha yang dilakukan untuk menanamkan nilai-nilai dan norma serta mewariskannya kepada generasi berikutnya untuk dikembangkan dalam hidup dan kehidupan yang terjadi dalam suatu proses pendidikan (Anwar, 2015).

Pendidikan di Indonesia ini berjalan karena adanya kurikulum, namun dalam penerapan kurikulum masih banyak terdapat permasalahan dan kurikulum pendidikan di Indonesia ini masih banyak mengalami bebrapa perubahan. Pada Kurikulum terbaru ini yaitu kurikulum 2013 diharapkan agar menghasilkan insan Indonesia yang aktif, kreatif, inovatif, afektif, melalui pemahaman, keterampilan, dan pengetahuan yang terintegrasi (Yulianti, 2017).

Kemampuan Pemahaman konsep berarti suatu proses mental intelektual untuk mengakomodasikan konsep yang baru diterima dan diasimilasikan dengan pengetahuan yang telah ada sehingga membentuk struktur kognitif yang baru (Triwahyuni, 2017).

Belajar konsep merupakan simbol berpikir walaupun siswa sudah memiliki kemampuan berpikir yang tinggi, belum tentu siswa juga sudah memiliki kemampuan pemahaman konsep yang tinggi. tanpa kemampuan berpikir mustahil bisa dapat memahami konsep dalam suatu materi pelajaran yang disampaikan guru kepadanya. Hal ini diperoleh dari hasil yang memuat tafsiran terhadap fakta atau realita serta hubungan terhadap berbagai fakta suatu konsep dapat diklasifikasikan berdasarkan ciri tertentu (Uno, 2012).

Sejalan dengan hal itu peneliti melakukan observasi di SMA Negeri 4 Palembang diketahui bahwa, berdasarkan hasil wawancara dan pengisian lembar angket yang dilakukan oleh guru mata pelajaran biologi kelas X di SMA Negeri 4 Palembang diketahui bahwa dalam suatu proses pembelajaran sekolah ini sudah menggunakan kurikulum 2013 dan dalam proses pembelajaran guru sudah menggunakan pendekatan saintifik, Saintifik merupakan proses pembelajaran yang mengaktifkan siswa dalam memahami konsep (Mustika, 2016).

Ada beberapa kendala yang dihadapi oleh guru dalam pembelajaran seperti kesalahan yang muncul dalam mata pelajaran biologi ini banyak peserta didik yang menganggap bahwa mata pelajaran biologi itu adalah mata pelajaran yang mengharuskan untuk dihapal sehingga biologi termasuk mata pelajaran yang membosankan, masih ada beberapa siswa yang kurang memperhatikan ketika guru sedang menjelaskan dan hanya mencatat materi saja. Selain itu juga kesulitan yang di alami oleh siswa dalam mata pelajaran biologi yaitu pada tingkat pemahaman. Sehingga menyebabkan beberapa siswa yang mendapatkan nilai dibawah KKM. Hal yang harus ditekankan bahwa mata pelajaran biologi bukan untuk menghapal segala namun untuk memahami. Dalam mata pelajaran biologi banyak siswa yang mengalami kesulitan dalam menyelesaikan soal walaupun bentuk soal tersebut hampir sama dengan soal yang pernah dipelajarinya. Padahal pemahaman sangat berpengaruh besar terhadap hasil belajar siswa.

Kemampuan pemahaman konsep siswa sangat penting, karena dengan kemampuan pemahaman konsep siswa pada topik terbaru sangat dipengaruhi oleh pemahaman konsep siswa pada topik sebelumnya. Pemahaman konsep biologi antara satu konsep dengan konsep yang lainnya saling terkait karena kemampuan tersebut sangat menentukan keberhasilan penguasaan konsep siswa terhadap materi pembelajaran selanjutnya. Siswa dituntut untuk terlibat dalam proses mengemukakan sebuah jawaban dari permasalahan yang tertulis di tes soal pemahaman konsep siswa pada materi Pencemaran Lingkungan. Penelitian ini memilih materi pencemaran lingkungan disebabkan materi ini sering 
dianggap mudah oleh siswa dan selain itu, materi pencemaran lingkungan bersifat kontekstual dan cukup banyak permasalahan yang dapat dikaitkan dalam memahami konsepnya. Pencemaran lingkungan yang tampak jelas seperti halnya timbunan sampah di pasar-pasar, pendangkalan sungai yang penuh dengan kotoran, ataupun sesaknya napas karena asap knalpot ataupun cerobong asap pabrik. Dengan demikian siswa mampu memunculkan ide-ide yang berkaitan dengan pencemaran lingkungan sehingga siswa mampu menjawab permasalahan yang diberikan. Penelitian ini bertujuan untuk mengetahui Pemahaman Konsep Siswa pada Materi Pencemaran Lingkungan di SMA Negeri 4 Palembang.

\section{METODELOGI PENELITIAN}

\section{Metode dan Desain Penelitian}

Penelitian ini termasuk dalam jenis penelitian deskriptif. Adapun pendekatan yang digunakan dalam penelitian ini adalah pendekatan kuantitatif, karena analisis dalam penelitian ini menggunakan perhitungan statistik yaitu rata-rata (yang disajikan dalam bentuk persentase) dan distribusi frekuensi relatif. pemahaman konsep siswa pada Materi Pencemaran Lingkungan. Populasi dalam penelitian ini adalah siswa kelas XI IPA SMA Negeri 4 Palembang. Pengambilan sampel dalam penelitian ini dilakukan secara Total sampling atau sampel yang diambil yaitu seluruh anggota populasi. Sampel dalam penelitian ini adalah seluruh siswa kelas XI MIPA yang berjumlah 5 kelas dengan jumlah sebanyak 161 siswa di SMA Negeri 4 Palembang.

\section{Subjek Penelitian}

Dalam penelitian ini yang dijadikan popuasi adalah siswa kelas XI MIPA SMA Negeri 4 Palembang yang berjumlah 5 kelas dengan jumlah populasi 161 siswa. pengambilan sampel dalam penelitian ini menggunakan metode Total Sampling. Sampel dalam penelitian ini adalah seluruh siswa kelas XI MIPA.

\section{Instrumen Penelitian}

Instrumen yang digunakan pada penelitian ini adalah Soal Tes Pemahaman Konsep Siswa. Soal tersebut dalam bentuk esai soal digunakan untuk mengukur tingkat pemahaman konsep yang dimiliki oleh siswa. Sebelum soal tersebut digunakan dalam penelitian, soal tes tersebut terlebih dahulu di validasi dengan dosen dan uji cobakan kepada siswa. Sebuah instrumen dikatakan valid apabila mampu mengukur apa yang diinginkan dan dapat mengungkapkan data dari variabel yang diteliti secara tepat.

Uji validitas yang dilakukan terhadap instrumen ini adalah uji validitas isi. Validitas isi adalah jenis validitas yang diperhitungkan melalui pengujian terhadap isi alat ukur (soal tes). Uji validitas dilakukan agar memperoleh instrumen yang valid itu artinya suatu instumen yang tepat untuk mengukur apa yang diukur selanjtnya dilakukan uji reliabilitas. Suatu instrumen pengukuran dikatakan reliabel, jika pengukurannya konsisten, cermat dan akurat.

Sebelum mengkoreksi hasil tes dari lembar jawaban setiap siswa, peneliti harus memiliki pedoman penskoran. Pedoman penskoran merupakan pedoman untuk mengkoreksi hasil tes soal essay kepada siswa. Untuk memberikan skor berdasarkan jawaban yang ditulis siswa dilembar jawaban.

\section{Pengumpulan Data}

Wawancara dilakukan untuk memperoleh informasi secara langsung mengenai keadaan sekolah, bagaimana perilaku guru serta siswa dalam kegiatan belajar.

Metode dokumentasi yaitu merupakan cara mencari data mengenai halhal atau variabel data. Pada penelitian ini dokumentasi untuk mengumpulkan datadata yang berkenaan dengan objek penelitian. Data yang diambil seperti daftar nama siswa, daftar nilai dan lain sebagainya.

Salah satu instrumen yang digunakan dalam penelitian ini yaitu tes pemahaman konsep siswa dengan soal esai, soal esai tersebut digunakan untuk mengukur kemampuan pemahaman konsep yang 
dimiliki siswa, dan soal esai tersebut membentuk pengetahuan secara faktual. Tes digunakan untuk mengukur hasil belajar kognitif siswa. Kognitif yang dimaksud disini adalah kemampuan siswa dalam memahami konsep.

\section{Analisis Data}

Data yang didapat akan dianalisis secara kuantitatif. Analisis kuantitatif digunakan untuk menganalisis hasil tes siswa. Dengan Rakapitulasi hasil tes, skor yang didapat diubah dalam bentuk persentase. Rumus yang digunakan untuk menghitung persentase pencapaian pemahaman konsep siswa sebagai berikut.

$$
\text { Persentase }(\%)=\frac{\text { Skor yang diperoleh }}{\text { Skor Maksimal }} \text { X } 100
$$

Keterangan: Total skor maksimal $=$ skor maksimal $\mathrm{x}$ banyak siswa.

Keterangan: Total skor maksimal $=$ skor maksimal $\mathrm{x}$ banyak siswa.

Data penelitian yang telah dianalisis selanjutnya ditafsirkan berdasarkan pedoman konversi nilai menurut Arikunto (2013) yang ditampilkan pada Tabel 1.

Tabel 1. Pedoman Konversi Nilai

\begin{tabular}{cc}
\hline Persentase $\%$ & Kriteria \\
\hline $0-20 \%$ & Sangat Rendah \\
$21-40 \%$ & Rendah \\
$41-60 \%$ & Sedang \\
$61-80 \%$ & Tinggi \\
$81-100 \%$ & Sangat tinggi \\
\hline
\end{tabular}

(Arikunto, 2013)

\section{HASIL DAN PEMBAHASAN}

Data hasil penelitian yang digunakan dalam penelitian ini diperoleh dari lembar jawaban siswa saat menjawab soal esai yang diberikan pada materi pencemaran lingkungan. Instrumen soal esai digunakan untuk mengukur tingkat pemahaman konsep siswa di SMA Negeri 4 Palembang. Data dianalisis menggunakan Microsoft Excel dengan melihat persentase tingkat pemahaman konsep siswa.

Hasil tes tertulis pemahaman konsep siswa pada materi pencemaran lingkungan di SMA Negeri 4 Palembang semester ganjil tahun 2018 dengan kriteria rendah, (21-40\%) rendah, (41-60\%) sedang, (61-80\%) tinggi, (81-100\%) sangat tinggi. Hasil penelitian nilai tes, persentase nilai tersebut dapat dilihat pada Tabel 2.

Tabel 2. Hasil Tes Pemahaman Konsep Siswa Berdasarkan Indikator di SMA Negeri 4 Palembang

\begin{tabular}{|c|c|c|c|}
\hline $\begin{array}{l}\mathbf{N} \\
\mathbf{0}\end{array}$ & Indikator & $\begin{array}{c}P \\
(\%)\end{array}$ & Kriteria \\
\hline 1 & $\begin{array}{l}\text { Indikator } \\
\text { Menafsirkan }\end{array}$ & 75 & Tinggi \\
\hline 2 & $\begin{array}{l}\text { Indikator } \\
\text { Mencontohkan }\end{array}$ & 59 & Sedang \\
\hline 3 & $\begin{array}{l}\text { Indikator } \\
\text { Mengklasifikasik } \\
\text { an }\end{array}$ & 86 & $\begin{array}{l}\text { Sangat } \\
\text { Tinggi }\end{array}$ \\
\hline 4 & $\begin{array}{l}\text { Indikator } \\
\text { Merangkum }\end{array}$ & 71 & Tinggi \\
\hline 5 & $\begin{array}{l}\text { Indikator } \\
\text { Menyimpulkan }\end{array}$ & 48 & Sedang \\
\hline 6 & $\begin{array}{l}\text { Indikator } \\
\text { Membandingkan }\end{array}$ & 55 & Sedang \\
\hline 7 & $\begin{array}{l}\text { Indikator } \\
\text { Menjelaskan }\end{array}$ & 58 & Sedang \\
\hline & Rata-rata & 65 & Tinggi \\
\hline
\end{tabular}

Pemahaman konsep siswa berdasarkan indikator dapat juga dilihat pada Gambar 1 berikut ini.

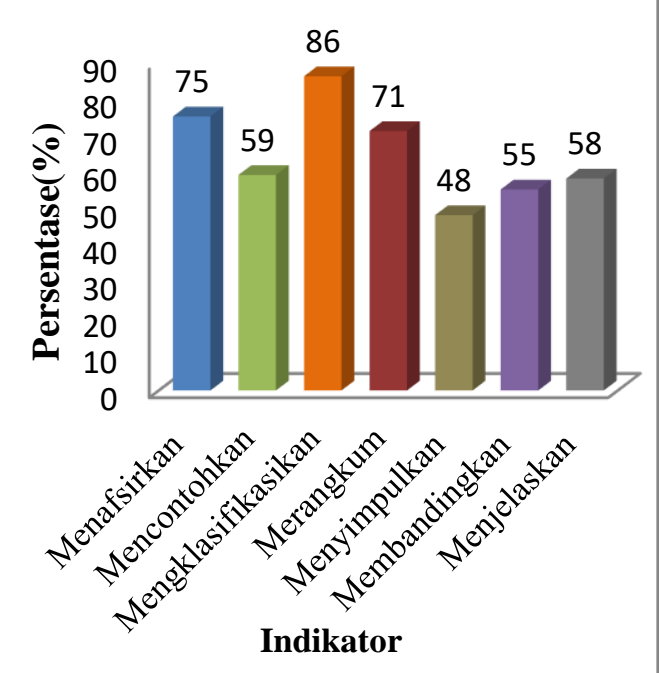


Gambar 4.1 Persentase berdasarkan Indikator Pemahaman Konsep Siswa di SMA Negeri 4 Palembang

\section{Analisis Pemahaman Konsep Siswa di SMA Negeri 4 Palembang}

Berdasarkan hasil persentase pemahaman konsep siswa di SMA Negeri 4 Palembang pada Tabel 2 dapat dianalisis bahwa nilai rata-rata pemahaman konsep siswa di SMA Negeri 4 Palembang yaitu sebesar $65 \%$ dengan kriteria tinggi.

\section{Analisis Pemahaman Konsep Siswa Berdasarkan Indikator di SMA Negeri 4 Palembang}

Berdasarkan Tabel 2 dan Gambar 1 di atas dapat dilihat hasil persentase menunjukkan bahwa di SMA Negeri 4 Palembang penguasaan indikator pemahaman konsep pada indikator menafsirkan sebesar $75 \%$ dengan kriteria tinggi, pada indikator mencontohkan yaitu sebesar 59\% dengan kriteria sedang, pada indikator mengklasifikasikan sebesar $86 \%$ dengan kriteria sangat tinggi, pada indikator merangkum sebesar $71 \%$ dengan kriteria tinggi, pada indikator menyimpulkan sebesar $48 \%$ dengan kriteria sedang, pada indikator membandingkan sebesar 55\% dengan kriteria sedang, pada indikator menjelaskan sebesar 58\% dengan kriteria sedang.

Tabel 3. Nilai Rata-Rata Tes Pemahaman Konsep berdasarkan kelas

\begin{tabular}{lcc} 
Kelas & $\begin{array}{c}\text { Rata- } \\
\text { Rata } \\
\text { Persentas } \\
\text { e (\%) }\end{array}$ & Kriteria \\
\hline XI MIPA 1 & 61 & Tinggi \\
\hline XI MIPA 2 & 66 & Tinggi \\
\hline XI MIPA 3 & 58 & Sedang \\
\hline XI MIPA 4 & 62 & Tinggi \\
\hline XI MIPA 5 & 74 & Tinggi \\
\hline
\end{tabular}

\section{Analisis Pemahaman Konsep Siswa Berdasarkan kelas XI di SMA Negeri 4 Palembang}

Berdasarkan analisis nilai rata-rata pemahaman konsep siswa kelas XI di SMA Negeri 4 Palembang pada Tabel 3 dapat dilihat bahwa nilai rata-rata pemahaman konsep siswa bervariasi yaitu mulai dari $58 \%$ sampai dengan $74 \%$. Tingkat pemahaman tertinggi terdapat pada kelas XI MIPA 5 dengan nilai rata-rata sebesar $74 \%$ dengan kriteria tinggi dan tingkat pemahaman terendah yaitu terdapat pada kelas XI MIPA 3 yaitu dengan nilai ratarata sebesar 58\% dengan kriteria sedang. Hal ini sesuai dengan hasil wawancara dengan guru biologi dan siswa kelas MIPA pada saat pengumpulan data awal, dari hasil wawancara guru biologi menyatakan bahwa dalam proses pembelajaran masih terdapat beberapa yang hanya mencatat materi saja. Sehingga ketika diberikan soal masih terdapat beberapa siswa yang belum mencapai nilai KKM.

Selain itu juga ada 2 faktor yang mempengaruhi diantaranya faktor internal yaitu bisa pengaruhi oleh faktor genetik orang tua. Faktor eksternal yaitu dari keadaan lingkungan dari tempat mereka tinggal meliputi sarana sosial, budaya, ekonomi dan pendidikan tempat mereka belajar (Yulianti, 2017).

Ada juga bebrapa hal yang menyebabkan siswa kurang memahami terhadap materi yang telah diajarkan, karena siswa hanya menghapal tanpa paham materi. Siswa dapat dikatakan memahami ketika siswa mampu untuk membangun makna dari pesan instruksional termasuk lisan, tertulis, dan grafis komunikasi, dan materi yang disampaikan (Effendi, 2017).

Hasil yang didapat oleh siswa tentunya tergantung pada proses pelaksanaan pembelajaran guru di kelas, apabila penguasaan kelas dikuasai oleh guru dalam proses pembelajaran berlangsung. Setiap siswa memiliki tingkatan pemahaman yang berbeda-beda terhadap suatu materi dan juga memiliki proses belajar yang berbeda-beda. Ada yang memahami materi secara menyeluruh, ada yang hanya memahami sebagian materi, 
bahkan ada pula yang sama sekali tidak dapat menangkap makna dari materi yang ia sedang pelajari, sehingga hanya sebatas mengetahui saja.

Siswa dikatakan memahami apabila siswa mampu menemukan dan menjelaskan kaitan konsep dengan konsep lainnya, dengan memahami konsep, siswa dapat mengembangkan kemampuannya dalam pembelajaran, siswa dapat menerapkan konsep yang telah dipelajarinya untuk menyelesaikan permasalahan sederhana sampai dengan yang kompleks (Utari, Fauzan \& Rosha, 2012).

Pemahaman konsep siswa pada kelas MIPA 3 lebih kecil dari pada kelas MIPA 5. Hal ini bisa disebabkan dari proses pembelajaran yang dilakukan guru, kelas XI MIPA 5 lebih dituntut untuk mencari sumber belajar lain setelah mengikuti pembelajaran didalam kelas dan sering mengadakan diskusi itulah sebabnya siswa terbiasa mengembangkan materi yang mereka dapat berdasarkan pemahman siswa itu sendiri. Berbeda dengan kelas MIPA 3 siswa kebanyakan hanya mencatat materi saja tanpa mengembangkan pemahaman mereka setelah mengikuti pembelajaran. Setiap individu memiliki tingkatan pemahaman yang berbeda-beda. Selama proses pembelajaran cara guru menyampaikan materi berbeda-beda ada yang mudah untuk dipahami dan ada yang tidak. Ada yang benar-benar memahami materi secara menyeluruh, ada yang memahami sebagian materi, dan ada pula yang sama sekali tidak dapat menangkap makna dari materi yang ia sedang pelajari, sehingga hanya sebatas mengetahui saja. Bahkan ada juga siswa ketika diberikan soal mereka hanya menghapal materi saja sehingga ada beberapa siswa yang belum paham dengan materi yang diajarkan.

Suatu pengetahuan akan diterima jika pengetahuan itu dianggap relevan dan konsisten untuk menyelesaikan masalah atau fenomena yang sesuai. Ini merupakan proses penyesuaian konsep-konsep dan ideide baru dengan kerangka berpikir, yang telah ada dalam pikiran mereka. Siswa dikatakan paham apabila mereka dapat mengkontruksi atau menjelaskan makna dari pembelajaran, baik itu yang bersifat lisan, tertulis ataupun grafis (Anderson \& Krathwohl, 2010).

Ada beberapa faktor yang dapat menyebabkan tingkat pemahaman konsep siswa berbeda yaitu dalam proses pembelajaran siswa hanya mencatat materi saja, tidak memperhatikan ketika guru menjelaskan materi, kurangnya jam pembelajaran. Selain itu juga ada 2 faktor yang mempengaruhi diantaranya faktor internal yaitu bisa pengaruhi oleh faktor genetik orang tua. Faktor eksternal yaitu dari keadaan lingkungan dari tempat mereka tinggal meliputi sarana sosial, budaya, ekonomi dan pendidikan tempat mereka belajar (Yulianti, 2017).

Kemampuan Pemahaman konsep berarti suatu proses mental intelektual untuk mengakomodasikan konsep yang baru diterima dan diasimilasikan dengan pengetahuan yang telah ada sehingga membentuk struktur kognitif yang baru (Triwahyuni, 2017).

Berdasarkan penelitian yang dilakukan oleh Yulianti (2017) dari penelitiannya dapat dikatakan bahwa pemahaman konsep ternyata mampu membantu peserta didik mengorganisasikan pemikiran mereka dan melakukan berbagai cara yang melakukan pemahaman yang lebih baik kepada penyelesaian masalah tersebut. Jika siswa memiliki kemampuan pemahaman konsep yang baik maka akan lebih mudah dalam proses pembelajaran pada materi selanjutnya.

\section{KESIMPULAN}

Berdasarkan hasil penelitian dan pembahasan yang telah di peroleh maka dapat ditarik kesimpulan sebagai berikut:

1. Pemahaman konsep siswa di SMA Negeri 4 Palembang pada materi Pencemaran Lingkungan dengan nilai rata-rata $65 \%$ yang termasuk kedalam kriteria tinggi.

2. Persentase tertinggi yaitu terdapat pada indikator mengklasifikasikan sebesar 86\% dengan kriteria sangat tinggi, dan Indikator terendah yaitu terdapat pada indikator menyimpulkan yaitu sebesar $48 \%$ dengan kriteria sedang. 


\section{UCAPAN TERIMA KASIH}

Penulis mengucapkan terima kasih kepada pihak yang telah memberikan dukungan untuk penelitian ini.

\section{DAFTAR PUSTAKA}

Agustina , L. (2016). Upaya Meningkatkan Pemahaman Konsep dan Pemecahan Masalah Matematika Siswa SMP Negeri 4 sipirok kelas VII Melalui Pendekatan Matematika Realistk (PMR). Jurnal Eksakta, 1 (1), 1-7.

Anderson, L. W., \& Krathwohl, D. R. (2010). Kerangka Landasan Untuk Pembelajaran, Pengajaran, dan Asesmen. Yogyakarta : Pustaka Pelajar.

Anwar, M. (2015). Filsafat Pendidikan. Jakarta: Prenadamedia Group.

Arifin, Z. (2009). Membangun Pedagogis Guru Matematika Landasan Filosofi, histologi dan fisikologi . Surabaya: Lentera Cendikia.

Arikunto, S. (2013). Dasar-Dasar Evaluasi Pendidikan . Jakarta: Bumi Aksara.

Effendi , R. (2017). Konsep Revisi Taksonomi Bloom dan Implementasinya Pada Pelajaran Matematika SMP. Jurnal Ilmiah Pendidikan Matematika, 2 (1), 72 78.

Lestari, D. D., Irwandi, A \& Bhaktl, K. (2017) Penerapan Model PBM Untuk Meningkatkan Kinerja dan Kemampuan Berpikir Kritis Siswa SMA. Jurnal Pendidikan dan Pembelajaran Biologi. 1(1), 46-52.

Murizal , A., Yarman, \& Yerizon. (2012). Pemahaman Konsep Matematis dan Model Pembelajaran Quantum Teaching. Jurnal Pendidikan Matematika, 1(1), 1923.

Mustika, Oen. 2016. Pengaruh Pendekatan Saintifik Berbasis Discovery Learning (DI) dan Problem Based Learning (PBL) Terhadap Hasil
Belajar Ditinjau dari Komunikasi Matematika. Biolmi. 1(2), 22-29.

Purwanto, N. (2010). Prinsip-Prinsip dan Teknik Evaluasi Pengajaran. Bandung: Remaja Rosda Karya.

Samudro , G. J. (2017). Pemahaman Relasional dan Instrumental Matematik Siswa Pada Model Pembelajaran Treffinger Pada Materi Operasi Hitung Bentuk Aljabar Kelas VIII. Kediri: FKIP Universitas Nusantara PGRI.

Sapuroh, S. (2010). Analisis Kesulitan Belajar Siswa Dalam Memahami Konsep di MAN Serpong Tanggerang. Jakarta: Pendidikan Ilmu Pengetahuan Alam Fakultas Ilmu Tarbiyah dan Keguruan. UIN Syarif Hidayatullah.

Triwahyuni, E. (2017) Pengaruh Pemahaman Konsep IPA Melalui Pendekatan Discovery Terbimbing Terhadap Hasil Belajar Siswa Kelas V sdn Wringinagung 1 Kecamatan Jombang Kabupaten Jember. Jurnal Inovasi.XXI (1), 1-7

Uno, H. (2012). Perencanaan Pembelajaran . Jakarta: PT Bumi Aksara.

Utari, V., Fauzan , A., \& Rosha, M. (2012). Peningkatan Kemampuan Pemahaman Konsep Melalui Pendekatan PMR Dalam Pokok Bahasan Prisma dan Limas. Jurnal Pendidikan Matematika Part 3.1 (1) ,33-38.

Yulianti , E. (2017). Analisis Pemahaman Konsep dan Pemecahan Masalah Biologi Berdasarkan Kemampuan Berpikir Kritis Pesera Didik Kelas XI SMA Alazhar 3 Bandar Lampung. Lampung: FKIP Universitas Islam Negeri Raden Intan .

Yustyan dkk. (2015). Peningkatan Kemampuan Berfikir Kritis Dengan Pembelajaran Berbasis Scientific Approach Siswa Kelas X SMA Panjura Malang. Jurnal Pendidikan Biologi Indonesia. 1 (2), 240-254. 